\title{
EROSION CONTROL WORKS AND THE INTENSITY OF SOIL EROSION IN THE UPPER PART OF THE RIVER TOPLICA DRAINAGE BASIN
}

\author{
Stanimir Kostadinov, Nada Dragović, Miodrag Zlatić , Mirjana Todosijević \\ Faculty of Forestry, Belgrade University \\ Kneza Višeslava 1, 11030 Belgarde, Serbia \\ kost@EUnet.yu
}

\begin{abstract}
Aiming at the protection of the future storage "Selova" against erosion and sediment, and also to protect the settlements and roads in the drainage basin against torrential floods, erosion control works in the upper part of the river Toplica basin, upstream of the storage "Selova", started in 1947. The works included buildingtechnical works (check dams) and biological works (afforestation and grassing of bare lands and other erosion risk areas). During the period 1947 - 2006, the following erosion control works were performed: afforestation of bare lands on the slopes 2,257.00 ha, grassing of bare lands 1,520.00 ha, and altogether 54 dams were constructed in the river Toplica tributaries. This caused the decrease of sediment transport in the main flow of the river Toplica.

This paper, based on the field research in two time periods: 1988 and in the period 2004-2007, presents the state of erosion in the basin before erosion control works; type and scope of erosion control works and their effect on the intensity of erosion in the river Toplica basin upstream of the future storage "Selova".
\end{abstract}

Keywords: soil erosion, sediment transport, effect of erosion control works.

\section{INTRODUCTION}

Properly designed and performed erosion control works cause the decrease of soil erosion intensity (Kostadinov, S., Marković, S., 1996; Kostadinov et al., 2000). In this respect, biological and technical works have different activities and effects. Biological works (afforestation, grassing, orchard establishment on terraces) are carried out on catchment slopes. They cause the lowering of erosion intensity and can reduce the intensity to normal geological erosion. Technical works can be longitudinal, which protect stream banks against erosion and sloughing, and transversal, which prevent bed erosion and retain the sediment (first of all bedload).

Of all water management structures, water storages are the most endangered structures by erosion and sediment.

In the storages, in addition to the decrease of the available storage capacity, sediment siltation also has chemical and biological impacts. By topsoil washing from the catchment slopes, the streams bring various chemical elements to the storage. The input elements can cause chemical and biological reactions, which affect water quality directly and significantly. The degree of risk imposed by the storage sediment depends on the quantity of sediment input, i.e. on the size of the drainage basin and erosion intensity in it. 
Aiming at the protection of the future storage "Selova" against erosion and sediment, and the defence of settlements and roads against torrential floods, erosion control works in the river Toplica drainage basin, upstream of the storage "Selova", started in 1947. The works consisted of building-technical works (check dams) and biological works (afforestation and grassing of bare lands and other areas endangered by erosion).

Based on field researches in two time periods: 1988 and 2004 - 2006, this paper presents the state of erosion in the drainage basin before the erosion control works; the type and scope of erosion control works, and their effect on the intensity of erosion in the river Toplica drainage basin upstream of the future storage "Selova".

\section{STUDY AREA AND METHOD}

\subsection{Study Area}

The River Toplica (South Serbia) is the largest left tributary of the Južna Morava, both by the water flow and by the basin area which is altogether $2,180 \mathrm{~km}^{2}$. The storage drainage basin encompasses the east slopes of Mt. Kopaonik. The storage "Selova" will be the source of water supply for the population of the settlements in the districts of Niš and Toplica. Other functions are: protection against flood, sediment storage, generation of hydro-energy, fish farming, irrigation, tourism, etc. The building works (rock filling) of the dam "Selova", on the river Toplica $18 \mathrm{~km}$ upstream of Kuršumlija, were completed in the spring 2007. The other accessory works were still to be completed, after which the filling of the storage could begin.

The storage controls $346.05 \mathrm{~km}^{2}$ of headwaters of the Toplica drainage basin. The main characteristics of the dam and of the storage are:

- Height of earth dam $.70 .6 \mathrm{~m}$

- Total storage volume. 70.5 mil. $\mathrm{m}^{3}$

- Volume of dead storage 7.3 mil. $\mathrm{m}^{3}$

- Elevation of the crest. $527 \mathrm{~m}$ a.s.l.

The dam is made of tipped rockfill, with slant clay core, with watertight diaphragm (curtain) of variable depth.

Drainage basin of the storage "Selova" is characterised by intensive erosion, which produce high quantities of sediment. The sediment transported by the Toplica and its tributaries will be delivered to the future lake, where it will be deposited, thus reducing the available storage capacity. It will also cause mechanical and chemical contamination of the water in the storage.

\subsection{Method}

The method consisted of the following phases:

1. Collection of documents and data on the state of erosion in the river Toplica drainage basin before the beginning of erosion control works;

2. Collection of documents and data on the type and scope of erosion control works;

3. Investigation of the drainage basin natural characteristics; 
4. Assessment of erosion intensity and distribution in the drainage basin in 1988;

5. Assessment of the state of erosion-control means: biological and technical.

6. Assessment of erosion intensity and distribution in the drainage basin in 2006;

7. Calculation of sediment yield and transport in different time periods;

8. Discussion of the results;

9. Conclusion.

The geological map of the drainage basin is based on map scale $1: 100,000$. The soil characteristics were determined based on the soil map of Serbia, issued by the Institute of Soil Science in Belgrade, scale 1:50,000, as well as by direct field (opening of the soil profiles) and laboratory study. Land use maps of the drainage basin for two time periods, 1988 and 2006, were based on satellite images and direct reconnaissance.

The assessment of erosion intensity and distribution in the drainage basin in 1956 was adopted from the existing technical documents. The intensities of soil erosion in 1988 and 2006 were defined based on erosion mapping. Erosion map was constructed by Gavrilović's methodology with the addition of satellite images and direct reconnaissance. Erosion map scale is $1: 25,000$.

Sediment yield and transport were calculated by Gavrilović's method, aiming at the comparison of the state of erosion in different time periods.

\section{RESULTS}

\subsection{The main physico-geographical characteristics of the drainage basin}

Table 1 presents the main parameters of the drainage basin, significant for the genesis of soil erosion processes and sediment transport. The drainage basin parameters point to a significant predisposition of the terrain for the development of intensive erosion processes and sediment transport.

Table 1. The main parameters of the drainage basin

\begin{tabular}{|c|c|c|}
\hline \multirow{2}{*}{ Parameters } & & \\
\hline & Symbol & Value \\
\hline Basin area & $A-\mathrm{km}^{2}$ & 346.05 \\
\hline Basin length & $L-k m$ & 33.2 \\
\hline Basin perimetre & $O-k m$ & 94.06 \\
\hline $\begin{array}{c}\text { Mean alevation of the } \\
\text { basin area }\end{array}$ & $N_{s r}-m . n . m$. & 971.10 \\
\hline Mean altitudinal diference & $D-m$ & 514.7 \\
\hline $\begin{array}{c}\text { Mean slope of the basin } \\
\text { area }\end{array}$ & $I_{s r}-\%$ & 37.44 \\
\hline Stream bed slope & $I_{t}-\%$ & 4.72 \\
\hline Local erosion basis & $H-m$ & $1,560.6$ \\
\hline Drainage density & $G-\mathrm{km} \cdot \mathrm{km}^{2}$ & 2.23 \\
\hline
\end{tabular}




\subsubsection{Bedrock composition and hydro-geological features of the terrain}

The lithologic composition, especially the development of the Tertiary clastic sediments, affects the development of instability and erodibility. Sericite-chlorite schists consist of fine-grained quartz, sericite and chlorite. They occur as the marginal, contact zone of the granodiorite massif Kopaonik. Crystalline limestones and marbles occur as alternating layers of crystalline limestones, dolomites and marbles. They also belong to the series of low-metamorphised rocks of the margin of Mt. Kopaonik granodiorite massif. Serpentinites are found in the east periphery of Ibarski ultrabasic massif. They occur in tectonised zones, often schistose and hydrothermally modified. Gabbros do not occur as large masses in the diabases of the Kuršumlija tectonic zone. Diabase-hornstone formation consists of sedimentary rocks and igneous rocks: sandstones, limestones, hornstone, argillites and diabases. It is in the tectonic relation with the surrounding rocks. The oldest sedimentary rocks are the Lower Cretaceous basal breccias, siltstones and sandstones. The most represented rocks are micro-conglomerates, arenytes, siltstones and marls. The calcareous sediments of the Senonian occur as layered slaty and massive reef limestones which occasionally end with marmorised limestones. The facies diversity of the Senonian flysch is characterised by alternating sandstones, siltstones and marls. Sedimentaryvolcanogenic series is represented by the rhythmical alteration of sandstones, marls, argillites, limestones and tuffs. Granitoid rocks consist of porphyroid quartzmoconites and granular granodiorites. The products of volcanic activity are quartzlatite rocks and minor masses of dacite-andesite. The youngest formations are the unbound sediments of alluvion, diluvial-proluvial screens and screes of the Quaternary period.

\subsubsection{Soil in the drainage basin of the storage "Selova"}

The following soil types are present in the drainage basin:

- Humus-siliceous soil with two subtypes:

- eutric on flysch, serpentinite, dacite-andesite, schists, gabbro-diabase and sandstone, and

- dystric on dacite-andesite, schists, flysch and sandstone.

- Brown soil, also in two subtypes

- eutric soil on flysch, andesite and gabbro-diabase and

- dystric soil on flysch.

- Chernozem on compact limestones

- Alluvial sediment

- Colluvium

- Lithosols, formed at places and forming a mosaic with humus siliceous soils and brown soils.

Of all the above soils, the most represented are eutric humus-siliceous soils on flysch on the area of about $133 \mathrm{~km}^{2}(52 \%)$, and then eutric humus-siliceous soils and lithosols on other parent rocks $66.87 \mathrm{~km}^{2}(19.2 \%)$.

Eutric brown soils cover the area of $9.25 \mathrm{~km}^{2}(2.65 \%)$, on about $38 \mathrm{~km}^{2}(10.9 \%)$. They are distributed in a conglomerate with humus-siliceous soils and lithosols. Dystric brown soils cover the area of $0.25 \mathrm{~km}^{2}$ and they are mosaically distributed with humus-siliceous and lithosols on about $1.0 \mathrm{~km}^{2}(2.9 \%)$. Chernozems occupy 
about $4 \mathrm{~km}^{2}(1.15 \%)$, and the colluviums cover $0.25 \mathrm{~km}^{2}$. Alluvial sediments, calcareous and non-calcareous loamy, deep, occur in the river valleys on the area of altogether $7.5 \mathrm{~km}^{2}(2.15 \%)$.

\subsubsection{Climate characteristics}

Climate, the most important physico-geographical factor, has an essential effect on hydrological features of the Toplica drainage basin, which is situated in the region of temperate continental climate (Central European climate). The headwater part of the drainage basin belongs to the mountain zone characterised by abundant atmospheric precipitation. Winters are severe and cold, and summers are fresh. Springs are changeable, with frequent alternation of warm and cold and windy days and frequent rains. Autumn is relatively warmer than spring.

Mean air temperature in a multiannual period, measured at the weather station Kuršumlija, as the nearest to the drainage basin, is $10.3^{\circ} \mathrm{C}$. January is the coldest month and the only month in the year with negative mean monthly temperature ($0.49^{\circ} \mathrm{C}$ ). The warmest month is July, with $19.8^{\circ} \mathrm{C}$. Based on the isohyet map of the drainage basin, the mean multiannual precipitation sum amounts to $891.9 \mathrm{~mm}$. In addition to precipitation and temperature, the regime of water and sediment in the drainage basin is also affected by wind. An especially high effect is that of the spring south wind "jugovina" which melts the snow which remains even in April in the higher parts of the drainage basin (above 1,200 m). Snow melting becomes fast and leads to sudden increase of water level, and great quantities of mud are delivered to the watercourses.

Table 2. Mean monthly and annual precipitations for the river Toplica drainage basin, upstream of the storage "Selova"

\begin{tabular}{|c|c|c|}
\hline Station & Annual values & $\begin{array}{c}\text { Period of the } \\
\text { measurement }\end{array}$ \\
\hline Kuršumlija & 639.4 & $1946-2003$ \\
\hline Velika Šatra & 828.5 & $1955-1999$ \\
\hline Selova & 669.8 & $1955-1999$ \\
\hline Lukova & 931.3 & $1951-1999$ \\
\hline Štave & 908.4 & $1955-1999$ \\
\hline Kopaonik & 959.4 & $1950-2003$ \\
\hline Trećak & 714.5 & $1954-1999$ \\
\hline Blaževo & 812.1 & $1946-2003$ \\
\hline
\end{tabular}

\subsubsection{State of vegetation in the drainage basin}

The greatest part of the drainage basin area is occupied by forests (more than $40 \%$ ) and thin - degraded forests (about 14\%)

Forest associations in the drainage basin are as follows:

1. Forest of Hungarian oak and Turkey oak (Quercetum farnetto cerris) is climateogenic forest of this part of Serbia and it covers the greatest part of the area under forests.

2. Forest of sessile oak (Quercus petraeae s.lat.) is a belt above the forests of Hungarian oak and Turkey oak. 
3. Montane beech forest (Fagetum montanum Rud.) is for the most part orographically conditioned, i.e. it occurs as a permanent stage at the cooler and fresher sites of oak region.

4. Forest of beech and fir (Abieto-Fagetum serbicum Jov.) grows above montane beech forests and occupies a significantly smaller area.

Table 3 presents land use in the drainage basin in two time periods: 1988 and 2006.

Table 3. Land use in the drainage basin in 1988 and 2006

\begin{tabular}{|r|c|c|c|c|c|}
\hline \multirow{2}{*}{ No } & \multirow{2}{*}{ Culture } & \multicolumn{2}{|c|}{$\mathbf{1 9 8 8}$} & \multicolumn{2}{c|}{$\mathbf{2 0 0 6}$} \\
\cline { 3 - 6 } & & $\mathbf{k m}^{\mathbf{2}}$ & $\mathbf{\%}$ & $\mathbf{k m}^{\mathbf{2}}$ & $\mathbf{\%}$ \\
\hline 1. & Forests & 140.29 & 40.54 & 149.03 & 43.07 \\
\hline 2. & Degraded forests & 49.26 & 14.23 & 48.05 & 13.88 \\
\hline 3. & Meadows and pastures & 57.61 & 16.65 & 72.81 & 21.04 \\
\hline 4. & Degraded pastures & 12.55 & 3.63 & 11.47 & 3.31 \\
\hline 5. & Plughed land & 25.89 & 7.48 & 13.21 & 3.82 \\
\hline 6. & Mixed cultures & 29.72 & 8.59 & 29.19 & 8.44 \\
\hline 7. & Bare land & 23.87 & 6.90 & 15.43 & 4.46 \\
\hline 8. & Setlements & 6.86 & 1.98 & 6.86 & 1.98 \\
\hline \multicolumn{2}{r|}{ Total } & $\mathbf{3 4 6 . 0 5 0}$ & $\mathbf{1 0 0 . 0 0}$ & $\mathbf{3 4 6 . 0 5}$ & $\mathbf{1 0 0 . 0 0}$ \\
\hline
\end{tabular}

Agricultural areas include farmlands, pastures, orchards and meadows. A special group consists of: farmsteads, meadows, thin forests, pastures and orchards, as the areas where, all these land uses occur on a small space, on somewhat gentler slopes, usually with medium intensity of erosion, so they have not been dealt with separately for rationality purposes.

\subsection{Soil erosion before erosion control works}

At the beginning of the fifties of the last century, it was decided to construct the dam and the storage "Selova" in the river Toplica drainage basin, for the purposes of water supply of Prokuplje, Blace, Merošine and Niš. In 1953, the river Toplica drainage basin became an experimental drainage basin for hydrological research. Based on the field reconnaissance, it was concluded that the prevailing water erosion processes in the drainage basin were very intensive, i.e. between intensive and, excessive according to Gavrilović's classification, with the coefficient of erosion Z= 1.0 .

The most intensive erosion processes occurred in the drainage basins of the following tributaries of the river Toplica: Mala Reka, Kačaruša, Đerekarska Reka, Pavaštička Reka and in the upper part of the Lukovska Reka drainage basin. The observed erosion processes were: sheet, rill and gully erosion, as well as landslides.

The state of erosion in the drainage basin can be illustrated also by the transport of sediment from the drainage basin. Table 7 presents the calculation of sediment yield and transport by Gavrilović's method in three different periods: 1956, 1988 and 2006.

\subsection{State of erosion in 1988}

There was a considerable decrease of erosion intensity compared to the state in 1956. This was, by all means, the consequence of the performed erosion control 
works. Based on erosion map in 1988, the coefficient of erosion was calculated after Gavrilović, for the entire drainage basin upstream of the storage "Selova" and it amounted to $Z=0.49$, which means that medium erosion processes prevailed in the drainage basin, but sediment yield and transport were high.

\subsection{Erosion control works and their effect}

Based on the data mainly obtained from enterprise "Erozija" Niš, Tables 4 and 5 present erosion control works in the Toplica drainage basin upstream of the storage "Selova". The works started in 1947, but very few, i.e. only five check dams were erected till 1968.

A much higher intensity of works was carried out in the period 1968-1987. The following works were intensified: building of check dams for bedload storage in the Toplica tributaries, and biological works (afforestation and grassing) on the drainage basin slopes. Afforestation was carried out on bare lands attacked by erosion. Most often, it was dense planting in pits, and the most frequently applied species were Austrian pine and Scotch pine. Grassing was performed on ploughlands on steep slopes and on bare lands, with the application of a special grass mixture for erosion control. The beginning of dam construction for the storage "Selova" focused public attention on the significance of erosion control works.

Table 4. Technical erosion control works in the river Toplica drainage basin upstream of the dam "Selova"

\begin{tabular}{|c|c|c|}
\hline \multirow{2}{*}{ Period } & \multicolumn{2}{|c|}{ Check dams } \\
\cline { 2 - 3 } & Number & $\begin{array}{c}\text { Masonry } \\
\mathbf{m}^{\mathbf{3}}\end{array}$ \\
\hline $1947-1968$ & 5 & $1,580.0$ \\
\hline $1968-1980$ & 34 & $2,881.3$ \\
\hline $1980-1987$ & 5 & $1,980.0$ \\
\hline Total 1947-1987 & 44 & $6,441.3$ \\
\hline $1988-2006$ & 10 & $4,182.0$ \\
\hline Total1947-2006 & 54 & $10,623.3$ \\
\hline Average annual & 0,90 & 177.06 \\
\hline
\end{tabular}

Table 5. Biological works in the river Toplica drainage basin upstream of the dam "Selova"

\begin{tabular}{|c|c|c|}
\hline Period & $\begin{array}{c}\text { Afforestation } \\
\text { ha }\end{array}$ & $\begin{array}{c}\text { Grassing } \\
\text { ha }\end{array}$ \\
\hline $1955-1987$ & 737.0 & 20.3 \\
\hline $1978-1987$ & $1,280.0$ & 930.7 \\
\hline $1988-2006$ & 240.0 & 380.0 \\
\hline Total 1955-2006 & $2,257.0$ & $1,520.0$ \\
\hline Average annual & 37.6 & 25.3 \\
\hline
\end{tabular}

\subsection{Analysis of the effects of erosion control works}

Total area treated by biological works is 3777.0 ha or $10.91 \%$ of the total area of the drainage basin. 
The effect biological works is expressed by the decrease of erosion intensity, i.e. the reduction of sediment yield in the treated areas. This is reflected on the reduction of sediment transport through the hydrographic network, which also reduces the intensity of siltation in the storage. Based on the detailed Erosion map produced in 1988 , it was concluded that erosion intensity in the drainage basin was significantly reduced compared to the state in 1956, when the drainage basin was attacked by severe erosion close to very severe erosion. Based on the mapping in 1988, the prevalent erosion process upstream of the storage "Selova" was medium erosion (after S. Gavrilović), with coefficient of erosion $Z=0.49$ (mean value for the whole drainage basin). It should be noted that there were some areas where afforestation was not completely successful, mostly in the headwater area of the Blaževska Reka (Boranačka Reka) drainage basin.

Another problem regarding the biological works is the fact that afforestation was most often performed by dense planting of conifers (more than 10,000 plants per $1 \mathrm{ha}$ ), which was not followed by tending measures, i.e. thinnings, etc. Such plantations do not have a good economic value now, and they are at risk caused by wildfires, decline, and due to too dense canopy, they are not resistant to snow-breaks and wind-breaks.

The building and technical works consisted of classical torrential dams. So far, altogether 54 check dams of different heights have been constructed, but the effective height of the majority of dams is between 3 and $5 \mathrm{~m}$. They are mainly made of stone masonry, mortarless stone and, somewhat less, of concrete. The effect of check dams is primarily reflected on bedload checking, stream stabilisation, reduction of torrent bed slope, by which, thanks to the lower transport competency of the stream, bedload delivery to the storage is indirectly reduced.

The greatest number of check dams is built of stone (dry dams, or dams in stone masonry). Only three dams are made of concrete, two in the Rankovica catchment, and one in Magovski Potok. A part of the check dams have a complete construction, with apron and subsidiary dam. As for the check dam dimensions, the check dam average height is about $3 \mathrm{~m}$, and the width of the dam mouth is 4-6 m.

\subsection{State of erosion in 2006}

Erosion map of the drainage basin is based on the research and field reconnaissance of the drainage basin in the period 2005 - 2006. Table 6 presents the distribution and intensity of erosion in the river Toplica drainage basin upstream of the dam "Selova" in 2006.

The coefficient of erosion for the whole drainage basin now is 0.404 , which means the prevalence of medium erosion processes, at the lower level, close to the weak erosion, according to Gavrilović's classification. Although the intensity and the scope of erosion control works in the period 1988 - 2006 was reduced compared to the previous period, the trend of reducing the intensity of erosion in the drainage basin continued, on the average. In addition to erosion control works, this was by all means also the result of demographic changes in the drainage basin in that period. Namely, the population from the mountainous villages which prevail in the drainage basin (except Lukovska Banja) migrates to the towns, looking for jobs. In future research, the problem of migrations and reducing the number of active population should be studied in more detail. 
Table 6. Erosion categories in the river Toplica drainage basin, 2006

\begin{tabular}{|c|c|c|c|c|c|}
\hline No & $\begin{array}{c}\text { Erosion } \\
\text { category }\end{array}$ & $\begin{array}{c}\mathbf{f} \\
\mathbf{k m}^{\mathbf{2}}\end{array}$ & $\mathbf{\%}$ & $\mathbf{Z}$ & $\mathbf{f ~ Z}$ \\
\hline 1. & weak & 149.029 & 43.07 & 0.30 & 44.7087 \\
\hline 2. & weak & 4.050 & 13.88 & 0.35 & 16.8175 \\
\hline 3. & medium & 72.807 & 21.04 & 0.50 & 36.4035 \\
\hline 4. & medium & 11.467 & 3.31 & 0.55 & 6.3069 \\
\hline 5. & medium & 13.210 & 3.82 & 0.65 & 8.5865 \\
\hline 6. & medium & 29.199 & 8.44 & 0.45 & 9.53955 \\
\hline 7. & intensive & 15.430 & 4.46 & 0.85 & 13.1155 \\
\hline 8. & medium & 6.858 & 1.98 & 0.65 & 4.4577 \\
\hline & Total & 346.050 & 100 & 0.404 & 139.93585 \\
\hline
\end{tabular}

The calculations of sediment yield and transport in 2006 indicate that in future considerable quantities of sediment will be delivered annually to the storage "Selova". In addition to the reduction of storage volume, great damage is caused by mechanical and chemical contamination of the storage water. Namely, together with soil particles, fertilisers (mineral and organic), are also washed down from the slopes, then pesticides applied in plant production, and also some heavy metals present in the soil in the upper parts of the drainage basin (Đerekarska Reka, Blaževska Reka, Mala Reka), which can have a serious impact of the water quality and cause additional costs for its purification.

Based on the so far performed erosion control works in the drainage basin upstream of the storage "Selova", and based on the actual state of erosion, it can be concluded that the system of erosion control protection is not complete. For this reason, the storage "Selova" is at risk, both by mechanical means (siltation), and by ecological means, because erosion sediment is the carrier of all types of chemical contamination.

Table 7. Intensity of erosion and mean annual sediment transport in the drainage basin before and after the erosion control works

\begin{tabular}{|c|c|c|c|c|c|c|c|}
\hline Period & $\begin{array}{c}\text { Erosion } \\
\text { intensity }\end{array}$ & $\begin{array}{c}\text { Erosion } \\
\text { category }\end{array}$ & $\begin{array}{c}\text { Erosion } \\
\text { coefficient } \\
-\mathbf{Z}\end{array}$ & $\begin{array}{c}\mathbf{W g o d} \\
\mathbf{m}^{3} \mathbf{y}^{-1}\end{array}$ & $\begin{array}{c}\mathbf{W g o d} / \mathbf{s p} \\
\mathbf{m}^{3} \mathbf{y}^{-1} \mathbf{k m}^{-2}\end{array}$ & $\begin{array}{c}\mathbf{G g o d} \\
\mathbf{m}^{3} \mathbf{y}^{-1}\end{array}$ & $\begin{array}{c}\mathbf{G g o d} / \mathbf{s p} \\
\mathbf{m}^{3} \mathbf{y}^{-1} \mathbf{k m}^{-2}\end{array}$ \\
\hline 1956 & $\begin{array}{l}\text { Intensive, } \\
\text { Excessive }\end{array}$ & I & 1.0 & $969,694.40$ & $2,802.2$ & $624,483, .8$ & $1,804.6$ \\
\hline 1988 & Medium & III & 0.49 & $332,605.2$ & 961.15 & $214,197.7$ & 619.0 \\
\hline 2006 & Medium & III & 0.404 & $249,004.3$ & 719.60 & $160,358.8$ & 463.4 \\
\hline
\end{tabular}


Toplica River Drainage Basin Upstream of "Selova" Reservoir: Soil Erosion Map - 2006 Year
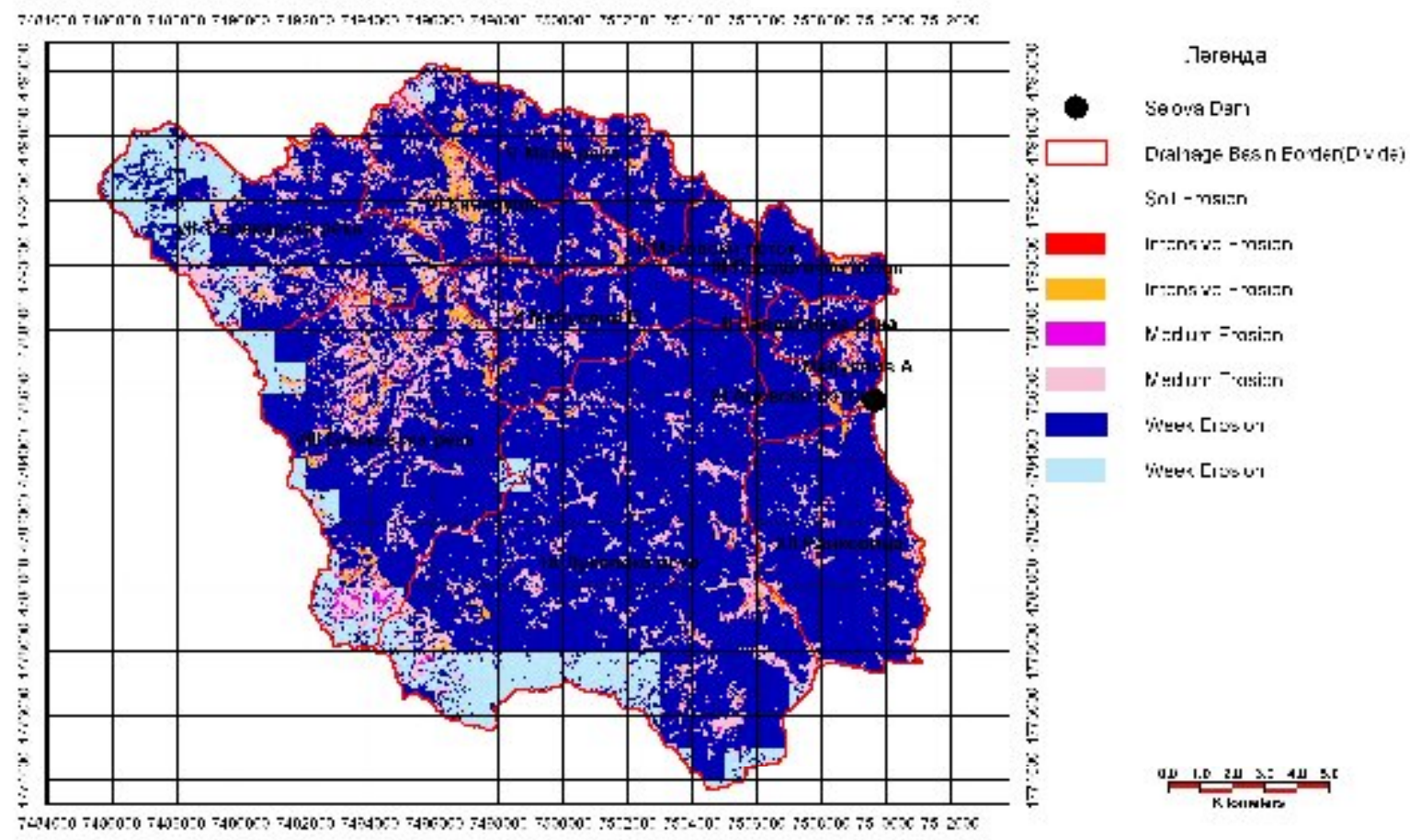

Figure 1. Erosion map of the Toplica river drainage basin

\subsection{Forecast of siltation dynamics of the storage "Selova"}

The process of suspended sediment deposition in the conditions of the established dam and storage "Selova" cannot be precisely analysed without the complex mathematical model. This model should take into account the regime of the storage, the regime of suspended sediment in the stream, as well as the coincidence of the torrential waves and the levels in the storage (the elevations from 468 to $526 \mathrm{~m}$ ). Taking into account the relatively great length of the zone of wedging out of the "Selova" backwater (about $7 \mathrm{~km}$ ) and hydraulic-morphological conditions in this zone, the greatest part of the coarser fractions of suspended sediment would be deposited in this sector (which is within the scope of the storage available capacity). Without the exact calculation, it is difficult to estimate which part of the total transport of suspended sediment would be deposited in the domain of the available storage capacity, but this percentage could attain even $60 \%$. This means that about 80,000 $\mathrm{m}^{3}$ of suspended sediment from the river Toplica would be deposited in the available storage capacity. In other words, the available capacity of the storage "Selova" would be reduced annually on the average by about $80,000 \mathrm{~m}^{3}$.

As for the bedload, it is certain that, in the conditions of the formed storage "Selova", this sediment would not reach the dead storage (below the elevation of 468). The main hydraulic reason of sediment retention is the insufficient transport competency of the slowed down river Toplica for the sediment of certain sizes. Taking into account the estimated average annual bedload transport of the Toplica and Lukovska Reka, annual volume of bedload deposits would amount to about $20,000 \mathrm{~m}^{3}$.

Based on the above, it can be concluded that, in the silting up process of the storage "Selova", annual deposition in the available storage capacity amounts to about 
$80,000 \mathrm{~m}^{3}$ of suspended sediment, and about $20,000 \mathrm{~m}^{3}$ of bedload. The loss of the available storage capacity of about $100,000 \mathrm{~m}^{3} /$ year is relatively small compared to its total size $\left(70 \cdot 10^{6} \mathrm{~m}^{3}\right)$. However, this does not mean that no measures should be taken for the reduction of sediment input in the storage. The erosion control management of the drainage basin would surely have very beneficial effects, both for the lowering of the lake silting up with sediment, and from the aspect of ecological and sanitation protection of the storage "Selova", aiming at the preservation of water quality.

\section{CONCLUSION}

The results of the research in the river Toplica drainage basin upstream of the dam "Selova", show a very significant effect of erosion control works on the decrease of intensity of erosion, the consequence of which is a considerable decrease of sediment yield and transport.

The greatest part of erosion control works was performed in the period 1967 - 1987. That was the period of the greatest decrease of erosion process intensity, sediment yield and sediment transport in the drainage basin.

In the period before 1956, there were very intensive water erosion processes in the upper part of the river Toplica drainage basin. The value of erosion coefficient was $Z$ $=1.0$ (severe to very severe erosion), the value of sediment yield was $W_{\text {year }}=2,802$ $\mathrm{m}^{3}$ year ${ }^{-1} \mathrm{~km}^{-2}$, and sediment transport $\mathrm{G}_{\text {year }}=1,804.6 \mathrm{~m}^{3} \mathrm{year}^{-1} \mathrm{~km}^{-2}$.

After large-scale erosion control works, the research in 1988 showed a significant decrease of the values of erosion intensity, sediment yield and transport: $Z=0.49$ (medium erosion), $W_{\text {year }}=961.15 \mathrm{~m}^{3}$ year $\mathrm{km}^{-2}$ and $\mathrm{G}_{\text {year }}=619.0 \mathrm{~m}^{3}$ god $^{-1} \mathrm{~km}^{-2}$ respectively.

At the end of the study period, in 2006, the intensity of erosion, sediment yield and transport were lower than in 1988: $Z=0.404$ (medium erosion at the lower level, close to weak erosion); $W_{\text {year }}=719.60 \mathrm{~m}^{3}$ year ${ }^{-1} \mathrm{~km}^{-2}, \mathrm{G}_{\text {year }}=463.4 \mathrm{~m}^{3}$ year ${ }^{-1} \mathrm{~km}^{-2}$ respectively.

Although in the period $1988-2006$ there was a reduction of erosion control works, the trend of decreasing intensity of erosion, sediment yield and transport continued, but with a lower rate of decrease. This can be explained by the fact that biological works performed in the period 1980 - 1987, attained their full functionality by the mid nineties of the $20^{\text {th }}$ century, when the canopy of the new forest plantations was established, also the result of demographic changes in the drainage basin in that period.

In the last 60 years, sediment yield and transport in the river Toplica drainage basin, upstream of the dam and the storage "Selova", decreased by almost four times, however every year, considerable volumes of sediment will still reach the future storage "Selova". The reason is the fact that erosion control system has not yet been completed. The problem is not the quantity of sediment, i.e. the storage siltation, but a much more significant problem is the mechanical and chemical contamination of storage water by the sediment. Namely, together with suspended sediment, many chemically detrimental substances will be delivered to the storage: organic and mineral fertilisers, pesticides, and other substances found in the soil, and among them some heavy metals. For this reason, it is necessary to go on with erosion control works in the drainage basin, especially in its headwater part., in order to 
protect the storage "Selova" against sediment silting up and to protect the water quality.

\section{References}

Gavrilović,S. (1972): Inženjering o bujičnim tokovima i eroziji. Časopis „Izgradnja”, Beograd , Specijalno izdanje.

Kostadinov, S.,(1996):Soil Erosion and Sediment Transport Depending on Land Use in the Watershed; In the book:"Hydrological Problems and Environmental Management in Highlands and Headwaters"; Edited by: Josef Krecek, G.S. Rajwar and Martin J. Haigh. Oxford and IBH Publishing CO. PVT. LTD. New delhi, Calcuta; p.p. 43-51

Kostadinov, S., Marković, S.(1996): Soil Erosion and Effects of Erosion Control Works in the Torrential Drainage Basins In South - East Serbia. IAHS Publication no 236 (ISSN 0144-7815) "Erosion and Sediment Yield: Global and Regional Perspectives " Edited by: D. E. Walling and B. W. Webb, IAHS Press Walingford, England. p.p. 321-332

Kostadinov,S., Zlatić,M., Dragović,N., ( 2000):Effects of Erosion Control Works in the Grdelička Klisura Gorge. Zbornik radova: " 75 godini visše lesotehničesko obrazovanie v Balgaria”; sekcija : Gorsko stopanstvo; Lesotehničeski universitet, Sofia, str. 115-124.

Kostadinov,S., (2004) : Soil Erosion and Sediment Transport Within Small Torrential Drainage Basins of Serbia, Poster Report Booklet; Symposium AHS: Sediment transport through the fluvial system; Moscow, August 2004,p.p. 16-21

Petković, S., Kostadinov, S., et al (1989): Studija antierozione zaštite sliva akumulacije "Selova«, Šumarski fakultet, Beograd. 